\title{
Fatal central nervous system co-infection with SARS-CoV-2 and tuberculosis in a healthy child
}

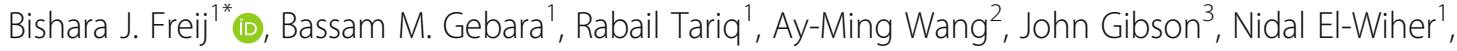 \\ Graham Krasan', Paul M. Patek ${ }^{4}$, Kelly A. Levasseur ${ }^{4}$, Mitual Amin $^{3}$ and Joseph M. Fullmer ${ }^{3}$
}

\begin{abstract}
Background: Central and peripheral nervous system symptoms and complications are being increasingly recognized among individuals with pandemic SARS-CoV-2 infections, but actual detection of the virus or its RNA in the central nervous system has rarely been sought or demonstrated. Severe or fatal illnesses are attributed to SARSCoV-2, generally without attempting to evaluate for alternative causes or co-pathogens.

Case presentation: A five-year-old girl with fever and headache was diagnosed with acute SARS-CoV-2-associated meningoencephalitis based on the detection of its RNA on a nasopharyngeal swab, cerebrospinal fluid analysis, and magnetic resonance imaging findings. Serial serologic tests for SARS-CoV-2 IgG and IgA showed seroconversion, consistent with an acute infection. Mental status and brain imaging findings gradually worsened despite antiviral therapy and intravenous dexamethasone. Decompressive suboccipital craniectomy for brain herniation with cerebellar biopsy on day 30 of illness, shortly before death, revealed SARS-CoV-2 RNA in cerebellar tissue using the Centers for Disease Control and Prevention 2019-nCoV Real-Time Reverse Transcriptase-PCR Diagnostic Panel. On histopathology, necrotizing granulomas with numerous acid-fast bacilli were visualized, and Mycobacterium tuberculosis complex DNA was detected by PCR. Ventricular cerebrospinal fluid that day was negative for mycobacterial DNA. Tracheal aspirate samples for mycobacterial DNA and culture from days 22 and 27 of illness were negative by PCR but grew Mycobacterium tuberculosis after 8 weeks, long after the child's passing. She had no known exposures to tuberculosis and no chest radiographic findings to suggest it. All 6 family members had normal chest radiographs and negative interferon- $\gamma$ release assay results. The source of her tuberculous infection was not identified, and further investigations by the local health department were not possible because of the State of Michigan-mandated lockdown for control of SARS-CoV-2 spread.

Conclusion: The detection of SARS-CoV-2 RNA in cerebellar tissue and the demonstration of seroconversion in $\lg G$ and IgA assays was consistent with acute SARS-CoV-2 infection of the central nervous infection. However, the cause of death was brain herniation from her rapidly progressive central nervous system tuberculosis. SARS-CoV-2 may mask or worsen occult tuberculous infection with severe or fatal consequences.
\end{abstract}

Keywords: SARS-CoV-2, CNS tuberculosis, Meningoencephalitis, Pediatric infections, Case report

\footnotetext{
* Correspondence: Bishara.Freij@beaumont.org

'Beaumont Children's Hospital, Beaumont Health, 3601 West 13 Mile Road,

Royal Oak, MI 48073, USA

Full list of author information is available at the end of the article
}

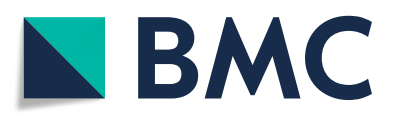

(c) The Author(s). 2020 Open Access This article is licensed under a Creative Commons Attribution 4.0 International License, which permits use, sharing, adaptation, distribution and reproduction in any medium or format, as long as you give appropriate credit to the original author(s) and the source, provide a link to the Creative Commons licence, and indicate if changes were made. The images or other third party material in this article are included in the article's Creative Commons licence, unless indicated otherwise in a credit line to the material. If material is not included in the article's Creative Commons licence and your intended use is not permitted by statutory regulation or exceeds the permitted use, you will need to obtain permission directly from the copyright holder. To view a copy of this licence, visit http://creativecommons.org/licenses/by/4.0/ The Creative Commons Public Domain Dedication waiver (http://creativecommons.org/publicdomain/zero/1.0/) applies to the data made available in this article, unless otherwise stated in a credit line to the data. 


\section{Background}

Except for the multisystem inflammatory syndrome in children, pandemic SARS-CoV-2 has been regarded as a milder respiratory and/or gastrointestinal infection in children, with lower rates of hospitalization and death as compared with adults [1-3]. Coronaviruses have been shown to be neuroinvasive in humans and animal models $[4,5]$. In a retrospective study of 214 Chinese adults with COVID-19, many of whom had chronic underlying diseases, 78 (36.4\%) exhibited neurologic symptoms including headache, dizziness, hyposmia, ischemic stroke, and cerebral hemorrhage [6]. In another series from France, $84 \%$ of 58 consecutive adults (median age, 63 years) admitted to the hospital with acute respiratory distress syndrome due to COVID-19 had neurologic symptoms such as agitation, corticospinal tract signs, and dysexecutive syndrome. MRI of the brain was performed in 13, of whom 8 had leptomeningeal enhancement and all exhibited perfusion abnormalities. Cerebrospinal fluid (CSF) analysis was only done in 7, and all had negative reverse transcriptase PCR assays for SARS-CoV-2 RNA [7]. Demonstration of SARS-CoV-2 RNA in the central nervous system (CNS) has only been documented in three adults, one with a positive CSF RNA result, one using genome sequencing in CSF, and another utilizing transmission electron microscopy on brain tissue obtained post-mortem $[5,8,9]$. Pulmonary co-infections with common viral, bacterial, and fungal pathogens have been described in COVID-19 patients, but there is a paucity of literature on mycobacteria, including members of the Mycobacterium tuberculosis complex with which a third of the world population is infected [10-17]. We describe the unique case of a previously healthy child with acute SARS-CoV-2 infection, fever, and headache, with laboratory and imaging evidence of meningoencephalitis who rapidly deteriorated 2 weeks into her illness and was found to have both SARS-CoV-2 RNA and Mycobacterium tuberculosis complex DNA on a cerebellar biopsy with histopathology consistent with tuberculous meningitis, with the recovery of Mycobacterium tuberculosis from two tracheal aspirates several weeks after she died. This report illustrates the need to consider that the toll of COVID19-associated morbidity and mortality may not all be due to the virus.

\section{Case presentation}

A healthy five-year-old African American girl was admitted on the sixth day of fever $\left(>39^{\circ} \mathrm{C}\right)$ and severe headache after 3 days of amoxicillin treatment for group A streptococcal pharyngitis. Initial laboratory data included a white blood cell count of 10.8 bil/L (lymphocytes 1.8 bil/L), Westergren sedimentation rate $30 \mathrm{~mm} / \mathrm{h}$, sodium $133 \mathrm{mmol} / \mathrm{L}$, normal liver enzyme concentrations, and clear chest radiograph. Nasopharyngeal swab was positive for SARS-CoV-2 RNA using the NxTAG ${ }^{\circledR} \mathrm{CoV}$ Extended Panel (Luminex). Her parents were recently ill with respiratory tract infections and SARS-CoV-2 IgG was positive after their recovery. Daily fever and headache persisted. A head CT scan on day 9 of illness was normal. She was discharged on day 10 but then readmitted later that evening following an episode of confusion and associated extremity stiffening with the appearance of staring into space, which lasted for $2 \mathrm{~min}$. On readmission, CSF studies showed clear fluid with a white blood cell count of $24 / \mu \mathrm{L}$ (96\% lymphocytes), red blood cell count $152 / \mu \mathrm{L}$, protein $85 \mathrm{mg} / \mathrm{dL}$ (normal range, 1545 ), and glucose $22 \mathrm{mg} / \mathrm{dL}$ (normal range, 50-80). Meningitis/encephalitis nucleic acid amplification panel using FilmArray ${ }^{\circ} \mathrm{ME}$ (Biofire) was negative for herpes simplex virus, human herpes virus VI (HHV-6), varicella-zoster virus, enterovirus, cytomegalovirus, parechovirus, Cryptococcus neoformans/gatti, Escherichia coli K1, Haemophilus influenzae type b, Listeria monocytogenes, Neisseria meningitidis, Streptococcus agalactiae, and Streptococcus pneumoniae. SARS-CoV-2 RNA was not detected in CSF using the Centers for Disease Control and Prevention 2019-nCoV Real-Time Reverse Transcriptase-PCR Diagnostic Panel (CDC qPCR). CSF bacterial culture was sterile. Her peripheral blood white blood cell count was $11.1 \mathrm{bil} / \mathrm{L}$ (lymphocytes $1.1 \mathrm{bil} / \mathrm{L}$ ), platelet count $366 \mathrm{bil} / \mathrm{L}$, sodium $130 \mathrm{mmol} / \mathrm{L}$, ferritin $137 \mathrm{ng} / \mathrm{mL}$, lactate dehydrogenase (LDH) $411 \mathrm{U} / \mathrm{L}, \mathrm{d}-$ dimer $972 \mathrm{ng} / \mathrm{mL}$, fibrinogen $316 \mathrm{mg} / \mathrm{dL}$, troponin $\mathrm{I}<$ $0.01 \mathrm{ng} / \mathrm{mL}$, and interleukin 6 level $<5 \mathrm{pg} / \mathrm{mL}$. Oral hydroxychloroquine $(6.5 \mathrm{mg} / \mathrm{kg} /$ dose every $12 \mathrm{~h}$ for two doses and then $3.5 \mathrm{mg} / \mathrm{kg} /$ dose per dose every $12 \mathrm{~h}$ for four more days) plus oral azithromycin $10 \mathrm{mg} / \mathrm{kg} /$ day for 5 days were started. Magnetic resonance imaging (MRI) of the brain with gadolinium on day 12 of illness revealed a $7 \mathrm{~mm}$ area of restriction diffusion involving the subcortical white matter of the medial aspect of the left anterior frontal lobe with increased T2 FLAIR signal without pathological enhancement (Fig. 1a). Mild leptomeningeal enhancement was noted (Fig. 1b). She developed SIADH (syndrome of inappropriate secretion of antidiuretic hormone) that was managed with fluid restriction and frequent 3\% saline boluses. Her fever persisted but she was neurologically stable with waxing and waning cognition and headache, until day 15 when she became more lethargic and developed asymmetric pupils. Head CT scan showed enlargement of the lateral, third, and fourth ventricles. On day 16, repeat lumbar puncture showed an opening pressure of $35 \mathrm{~cm}$ of water. CSF studies revealed a hazy fluid with a white blood cell count of $160 / \mu \mathrm{L}$ (44\% neutrophils, 51\% lymphocytes, 5\% monocytes), red blood cell count $7 / \mu \mathrm{L}$, glucose $30 \mathrm{mg} /$ $\mathrm{dL}$, and protein $112 \mathrm{mg} / \mathrm{dL}$; HHV-6 DNA was detected 


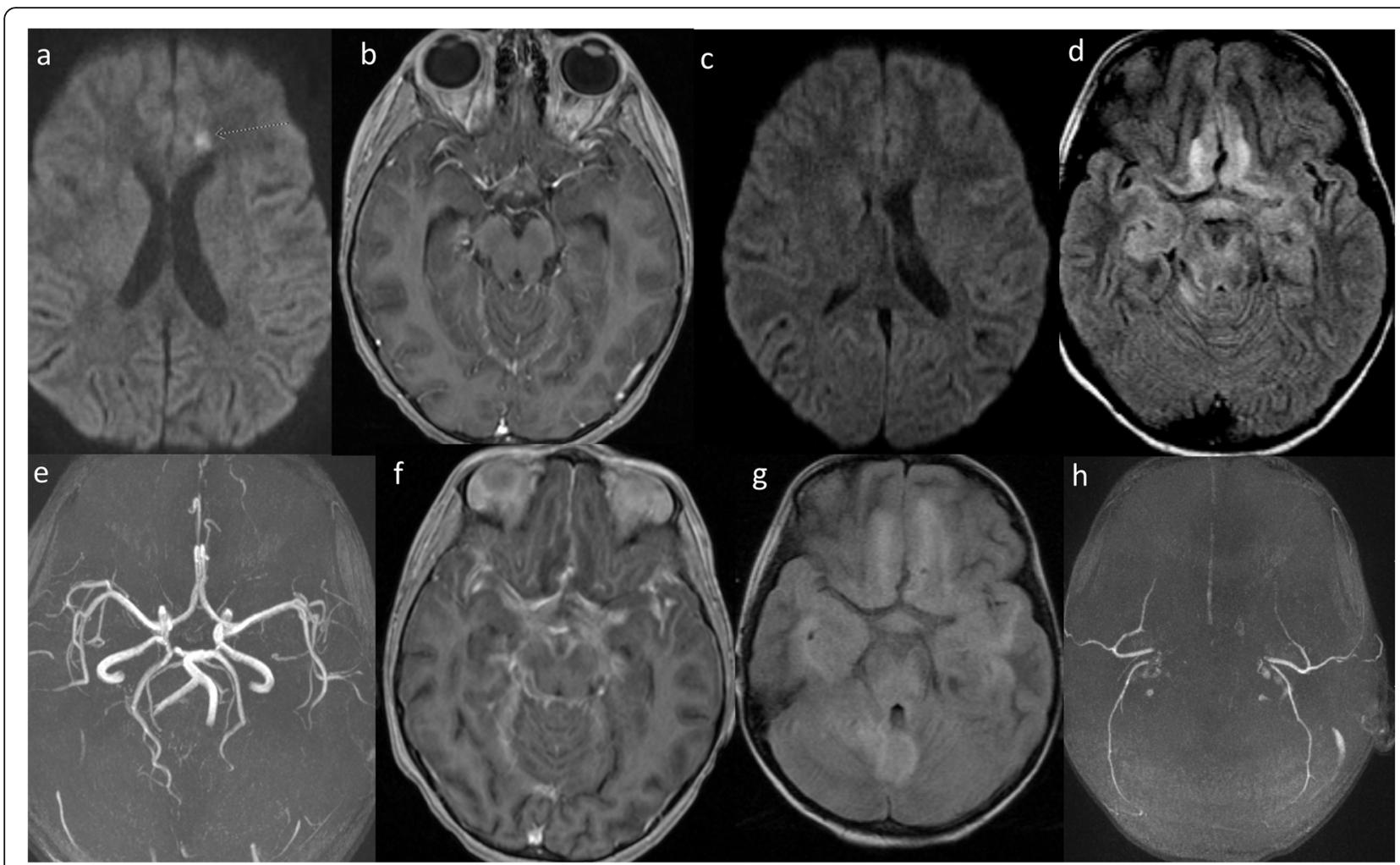

Fig. 1 Selected sequential MRI/MRA images. a Diffusion-weighted image shows a $7 \mathrm{~mm}$ area of restriction diffusion in the left anterior frontal lobe subcortical white matter (arrow), day 12 of illness; $\mathbf{b}$ T1-weighted image with gadolinium showing mild leptomeningeal enhancement along the tentorium, day 12; c Diffusion-weighted image showing no restriction diffusion in the left anterior frontal lobe subcortical white matter, day 16; d T2 FLAIR shows abnormal increased signal mainly involving the midbrain, bilateral deep frontal, and bilateral medial temporal areas, day 16; e 3-D time of flight MRA shows a normal circle of Willis, day 16; $\mathbf{f}$ T1-weighted image with gadolinium showing diffuse leptomeningeal

enhancement, day 16; g T2 FLAIR showing extensive grey matter lesions involving the deep frontal lobe, temporal lobe, midbrain, and cerebellar vermis, with no obvious cerebellar involvement, day 30; $\mathbf{h}$ 3-D time of flight MRA showing no flow in intracranial vessels with flow in extracranial vessels, day 30

but not SARS-CoV-2 RNA. An external ventricular drain was placed the same day and the CSF was negative for both HHV-6 DNA and SARS-CoV-2 RNA. She had no HHV-6 DNA in plasma and her HHV-6 IgM was $<1$ : 20 and HHV-6 IgG 1:320 (negative if $<1: 10$ ), suggesting that the detection of HHV-6 DNA on lumbar CSF was a false-positive result. MRI of the brain showed extensive progression of the meningoencephalitis to her cerebellum and corpus callosum, with leptomeningeal enhancement especially over the surface of the brainstem and into the auditory canals; magnetic resonance angiography (MRA) was normal (Figs. 1c-f). Intravenous dexamethasone was initiated. On day 17, she was intubated for worsening encephalopathy and intravenous remdesivir was started. Her chest radiograph showed early perihilar streaky opacities. Ferritin, interleukin 6, and LDH concentrations were again normal.

The subsequent clinical course over the ensuing days was turbulent. She had ongoing SIADH, severe hypertension requiring multiple intravenous antihypertensive medications, worsening chest radiographic findings with development of bibasilar opacities on day 27, electroencephalography consistent with severe encephalopathy, and gradual neurologic worsening with minimally reactive and dilated pupils.

On day 30 of illness, MRI of the brain showed marked progression of inflammation with supratentorial and infratentorial edema, hypoxic/ischemic changes, cerebellar tonsillar herniation, and lack of normal flow at the circle of Willis (Figs. 1g-h). A midline suboccipital craniectomy and $\mathrm{C} 1$ laminectomy were performed. The cerebellum was necrotic and edematous, and herniated out of the surgical defect. She passed away on day 32 of illness.

\section{Additional laboratory data}

The absolute lymphocyte counts ranged between 0.41.8 , and all were $\leq 1.0$ during the last 2 weeks of her life. Her platelet count was normal throughout except for day 31 of illness (96 bil/L). AST, ALT, and total bilirubin concentrations between days 5 and 31 of illness (24 measurements each) were consistently normal. 
Ventricular CSF studies from days 23 and 28 were similar, with clear fluid and white blood cell counts of $1-10 / \mu \mathrm{L}$, red blood cell counts of $30-127 / \mu \mathrm{L}$, glucose $75-83 \mathrm{mg} / \mathrm{dL}$, and protein $53-55 \mathrm{mg} / \mathrm{dL}$. On day 30 , when she developed brain herniation, ventricular CSF was pale yellow with a glucose of $21 \mathrm{mg} / \mathrm{dL}$, protein 130 $\mathrm{mg} / \mathrm{dL}$, white blood cell count $6 / \mu \mathrm{L}$, and red blood cell count $174 / \mu \mathrm{L}$.

Human immunodeficiency virus (HIV) types $1 / 2$ antibodies and p24 antigen were negative. Antinuclear cytoplasmic antibody was undetectable.

Whole genome sequencing on blood did not reveal any abnormalities except for potential compound heterozygous $I L 12 R B$ variants that may explain susceptibility to mycobacterial disease. Studies are planned to test parental DNA to identify whether these variants are on the same or different alleles (personal communication, July 20, 2020, Helen Su, M.D., Ph.D, National Institute of Allergy and Infectious Diseases, National Institutes of Health, Bethesda, Maryland).

Stored CSF from day 16 of illness was later tested for autoantibodies (CSF Autoimmune Evaluation, Mayo Clinic Laboratories, Rochester, MN). Immunofluorescence antibody assay detected glial fibrillary acidic protein (GFAP) autoantibody at a titer of 1:8 (normal, <1:2).

\section{Microbiologic and immunologic studies}

Nasopharyngeal swabs remained positive for SARS-CoV2 RNA, including one collected on her last day of life. Tracheal aspirate SARS-CoV-2 RNA was negative on day 22 .

Tracheal aspirates for mycobacterial DNA detection and cultures were collected on days 22 and 27 of illness. Mycobacterium tuberculosis complex DNA was negative for both samples; however, they grew acid fast bacilli after 8 weeks, several weeks after the child's demise. The organism was later identified as Mycobacterium tuberculosis by the Michigan Department of Health and Human Services, and it was susceptible to isoniazid, rifampin, ethambutol, and pyrazinamide. Mycobacterial culture from ventricular CSF collected on day 25 was sterile. Mycobacterial DNA detection on ventricular CSF from day 28 of illness was negative.

The cerebellar brain biopsy was positive for SARSCoV-2 RNA (CDC qPCR). It was also positive for $M$. $t u$ berculosis complex DNA using an hsp65 amplified probe and negative for atypical mycobacterial DNA with $16 \mathrm{~s}$ rDNA, hsp65, and rpoB primer sets (University of Washington Medical Microbiology Laboratories, Seattle, WA). There was no fresh cerebellar tissue for mycobacterial culture.

SARS-CoV-2 IgA and IgG responses on day 11 of illness were weakly positive and negative, respectively. A strong antibody response evolved when re-tested on days
22 and 32 (Fig. 2). The findings were consistent with an acute SARS-CoV-2 infection.

The child had no history of travel and lived with her mother, father, and maternal grandmother, all of whom were positive for SARS-CoV-2 IgG but had negative interferon- $\gamma$ release assays and normal chest radiographs. She was also in frequent contact with her maternal aunt's family, consisting of 3 adults, all of whom had normal chest radiographs and negative SARS-CoV-2 IgG and interferon- $\gamma$ release assays. Schools had closed in Michigan because of the COVID-19 pandemic a week before her symptoms began. The source of her tuberculous infection has not been identified.

\section{Histopathology}

The cerebellar biopsy on day 30 of illness showed patchy areas of necrotizing granulomatous inflammation and vasculitis. Stains showed endothelial injury, muscle wall injury, and lost elastic lamina. Acid fast bacilli were identified (Fig. 3).

\section{Discussion and conclusions}

SARS-CoV-2 neurotropism is believed to be mediated by binding of its spike protein to its receptor angiotensin-converting enzyme 2 which is expressed in glial cells and neurons [18]. Neurologic abnormalities are increasingly recognized in SARS-CoV-2 infected individuals, but our knowledge is hampered by a dearth of information on associated CSF and neuroradiologic correlates of pathology and how they might evolve during a severe illness. Contributing to this knowledge gap are resource limitations including insufficient reagents for broader molecular testing and infection control concerns that limit diagnostic evaluations such as imaging studies, tissue biopsies, and autopsies. Severe or fatal illnesses are generally attributed to SARS-CoV-2, which may be inaccurate.

This child's clinical course was that of progressive clinical and radiologic worsening. She was shown to have an acute SARS-CoV-2 infection based on evolution of her serologic responses (Fig. 2). The CSF abnormalities were consistent with acute viral meningoencephalitis, and similar findings have been described in two adults with SARS-CoV-2-associated encephalitis [19]. However, her initial CSF glucose was concerning because it was unusually low for a viral infection. While tuberculous meningitis was considered during the course of her illness, it was deemed improbable given the lack of known exposures to tuberculosis (later confirmed by evaluation of all family members who proved to be free from infection), normal chest radiographs during the first 2 weeks of illness, and CSF findings that were uncommon for this diagnosis (commonly white blood cell counts of $100-500 / \mu \mathrm{L}$ and protein $>100 \mathrm{mg} / \mathrm{dL}$ ) [20]. Tracheal 


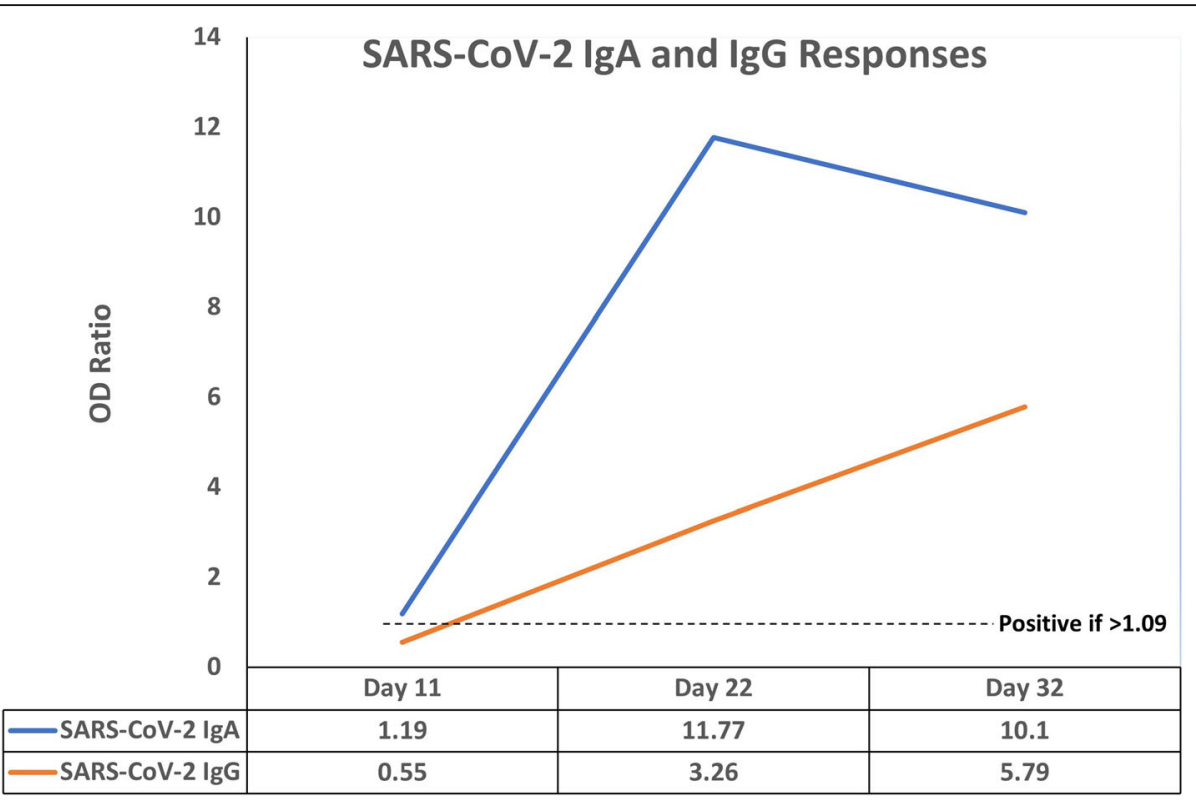

Fig. 2 Evolution of SARS-CoV-2 IgA and IgG responses by enzyme immunoassay (EUROIMMUN AG, Germany). OD = Optical density

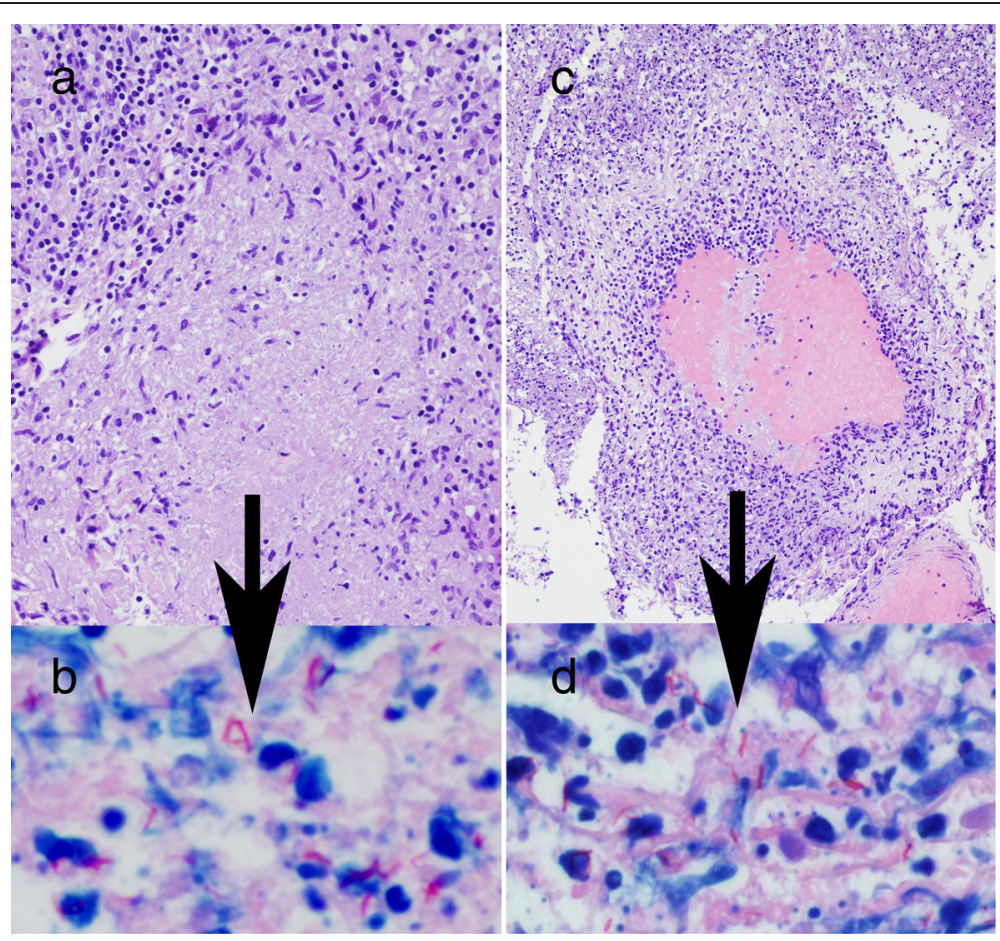

Fig. 3 Cerebellar biopsy histopathology. a High power view of a necrotizing granuloma showing central pale eosinophilic caseous-type necrosis; b High power view revealing numerous acid-fast bacilli within the granuloma; c Low power view of medium-sized blood vessel with numerous inflammatory cells and severe damage to the vessel wall with essentially complete loss of internal elastic lamina (vasculitis); $\mathbf{d}$ High power view revealing numerous acid-fast bacilli identified in same vessel wall. Hematoxylin-Eosin stained sections (a, $\mathbf{c})$; Fite stain (b, d) 
aspirate and CSF molecular tests were negative for mycobacteria. Nevertheless, normal chest radiographs in children with tuberculous meningitis are commonly encountered and are not sufficient to exclude the diagnosis [21]. In the pre-COVID-19 era, the diagnosis of tuberculous meningitis would have been considered possible and specific anti-tuberculous therapy empirically initiated [22].

We hypothesize that this child was asymptomatically infected with Mycobacterium tuberculosis when she acquired her SARS-CoV-2 infection. SARS-CoV-2 meningoencephalitis was confirmed by the positive cerebellar tissue PCR assay. The immunologic response to SARSCoV-2 may have contributed to CNS spread of mycobacteria, as detailed below. The cause of death was brain herniation secondary to rapidly progressive CNS tuberculosis.

Type I interferons (e.g., IFN- $\alpha$, IFN- $\beta$ ) are produced early during a viral infection and are critical in antiviral immunity. After attachment to the interferon $\alpha / \beta$ receptor and ensuing intermediary biochemical steps, interferon stimulated genes (ISGs) are activated [23]. Wei and colleagues demonstrated that genes functioning in viral defense, such as ISGs, are highly expressed in peripheral blood mononuclear cells of SARS-CoV-2 infected individuals requiring intensive care [24]. In one study, peak IFN 22 levels occurred on days 8-10 of symptom onset and gradually decreased over the following 2-3 weeks in critically ill adults [25].

Multiple studies have shown that viruses such as influenza, HIV, and measles can impair the ability of macrophages to contain mycobacterial growth, including Mycobacterium tuberculosis [26, 27]. In a mouse model of influenza A and M. tuberculosis, co-infection resulted in enhanced mycobacterial growth in the lungs and decreased survival mediated by type I IFN signaling [28]. Type I interferons also reduce the ability of macrophages to respond to IFN- $\gamma$ and control of intracellular growth of M. tuberculosis [29]. This child additionally had persistent lymphopenia, which is a risk factor for severe tuberculosis [30].

The detection of a high CSF GFAP autoantibody titer is indicative of an astrocytopathy. This autoantibody is often detected in individuals with meningoencephalitis [31]. Severe SIADH has previously been observed in a few adults with SARS-CoV-2 pneumonia [32].

This child's fatal illness raises broader concerns given the intersection of a global SARS-CoV-2 pandemic and an infection that afflicts a third of the world population. $\mathrm{He}$ and colleagues described 2 adults with a history of treated tuberculosis and one with a 50-year history of untreated but stable infection who acquired SARS-CoV2 infection and had severe pulmonary disease with protracted hospital stays, but survived; all were placed on anti-tuberculous drug therapy, but no microbiologic or molecular studies for Mycobacterium tuberculosis were attempted [12]. A number of other studies have examined small cohorts of adults with known tuberculosis and COVID-19 superinfection, all suggesting that those already on anti-tuberculous therapy may have a relatively benign course [14], although there is some evidence to the contrary [15]. In terms of tuberculous meningitis, we found a report of two adults who were on treatment but acquired COVID-19 53-152 days after their diagnosis. One had worsening chest radiographs and the other had improved imaging findings when compared to their last pre-COVID-19 studies; both survived [14]. A three-month-old Gambian child with COVID-19 was diagnosed with pulmonary and extrapulmonary tuberculosis (including meningitis) 3 days later and was placed on anti-tuberculous medications, but no details of how the diagnosis was reached were provided [16]. Further investigation into the role of co-infection by Mycobacterium tuberculosis and SARS-CoV-2 on severity and mortality is needed for both adults and children.

\section{Abbreviations}

CDC qPCR: Centers for Disease Control and Prevention 2019-nCoV Real-Time Reverse Transcriptase-PCR Diagnostic Panel; CNS: Central nervous system; CSF: Cerebrospinal fluid; CT: Computed tomography; HIV: Human immunodeficiency virus; IFN: Interferon; ISGs: Interferon stimulated genes

\section{Acknowledgements}

We thank Barbara Robinson-Dunn, Ph.D., for her critical review of the manuscript and Dr. Helen Su and her colleagues at the National Institute of Allergy and Infectious Diseases, National Institutes of Health, Bethesda, Maryland for performing whole genome sequencing.

\section{Authors' contributions}

All authors read and approved the manuscript. BJF prepared the initial and final drafts of the paper. AMW selected and provided the imaging studies (Fig. 1). MA and JMF prepared and selected the histopathology image (Fig. 3). BJF, BMG, RT, AMW, JG, NE, GH, PMP, KAL, MA, and JMF revised the paper critically for important intellectual content, approved the final version to be published, and agree to be accountable for all aspects of the work in ensuring that questions related to the accuracy and integrity of any part of the work are appropriately investigated and resolved.

\section{Funding}

None.

Availability of data and materials

Not applicable as no datasets were generated or analyzed for the current case report. Patient data are part of the protected electronic health system.

Ethics approval and consent to participate Not applicable.

\section{Consent for publication}

Written informed consent was obtained from the parent for the publication of this case report and any accompanying images. A copy of the written consent is available for review by the Editor of this journal. 


\section{Author details}

'Beaumont Children's Hospital, Beaumont Health, 3601 West 13 Mile Road, Royal Oak, MI 48073, USA. ${ }^{2}$ Department of Neuroradiology, Beaumont Health, Royal Oak, MI, USA. ${ }^{3}$ Department of Pathology, Beaumont Health, Royal Oak, MI, USA. ${ }^{4}$ Department of Emergency Medicine, Beaumont Health, Royal Oak, $\mathrm{MI}$, USA.

Received: 3 June 2020 Accepted: 20 August 2020

Published online: 09 September 2020

\section{References}

1. Liu W, Zhang Q, Chen J, Xiang R, Song H, Shu S, et al. Detection of Covid19 in children in early January 2020 in Wuhan, China. N Engl J Med. 2020; 382:1370-1.

2. Zimmermann $\mathrm{P}$, Curtis N. Coronavirus infections in children including COVID-19: an overview of the epidemiology, clinical features, diagnosis, treatment and prevention options in children. Pediatr Infect Dis J. 2020;39: 355-68.

3. Feldstein $L R$, Rose EB, Horwitz SM, Collins JP, Newhams MM, Son MBF, et al. Multisystem inflammatory syndrome in U.S. children and adolescents. N Engl J Med. 2020;383:334-46.

4. Li YC, Bai WZ, Hashikawa T. The neuroinvasive potential of SARS-CoV2 may play a role in the respiratory failure of COVID-19 patients. J Med Virol. 2020; 92:552-5.

5. Wu Y, Xu X, Chen Z, Duan J, Hashimoto K, Yang L, et al. Nervous system involvement after infection with COVID-19 and other coronaviruses. Brain Behav Immun. 2020;87:18-22.

6. Mao L, Jin H, Wang M, Hu Y, Chen S, He Q, et al. Neurologic manifestations of hospitalized patients with coronavirus disease 2019 in Wuhan, China. JAMA Neurol. 2020;77:683-90.

7. Helms J, Kremer S, Merdji H, Clere-Jehl R, Schenck M, Kummerlen C, et al. Neurologic features in severe SARS-CoV-2 infection. N Engl J Med. 2020;382: 2268-70.

8. Moriguchi T, Harii N, Goto J, Harada D, Sugawara H, Takamino J, et al. A first case of meningitis/encephalitis associated with SARS-Coronavirus-2. Int J Infect Dis. 2020;94:55-8.

9. Paniz-Mondolfi A, Bryce C, Grimes Z, Gordon RE, Reidy J, Lednicky J, et al. Central nervous system involvement by severe acute respiratory syndrome coronavirus-2 (SARS-CoV-2). J Med Virol. 2020;92:699-702

10. Lin D, Liu L, Zhang M, Hu Y, Yang Q, Guo J, et al. Co-infections of SARSCoV-2 with multiple common respiratory pathogens in infected patients. Sci China Life Sci. 2020;63:606-9.

11. Rawson TM, Moore LSP, Zhu N, Ranganathan N, Skolimowska K, Gilchrist M, et al. Bacterial and fungal co-infection in individuals with coronavirus: a rapid review to support COVID-19 antimicrobial prescribing. Clin Infect Dis. 2020:ciaa530. https://doi.org/10.1093/cid/ciaa530 [Epub ahead of print].

12. He G, Wu J, Shi J, Dai J, Gamber M, Jiang X, et al. COVID-19 in tuberculosis patients: a report of three cases. J Med Virol. 2020. https://doi.org/10.1002/ jmv.25943 [Epub ahead of print].

13. Mandal N, Anand PK, Gautam S, Das S, Hussain T. Diagnosis and treatment of paediatric tuberculosis: an insight review. Crit Rev Microbiol. 2017:43:466-80.

14. Stochino C, Villa S, Zucchi P, Parravicini P, Gori A, Raviglione MC. Clinical characteristics of COVID-19 and active tuberculosis co-infection in an Italian reference hospital. Eur Respir J. 2020;56(1):2001708. https://doi.org/10.1183/ 13993003.01708-2020.

15. Goussard P, Solomons RS, Andronikou S, Mfingwana L, Verhagen LM, Rabie H. COVID-19 in a child with tuberculous airway compression. Pediatr Pulmonol. 2020:1-3. https://doi.org/10.1002/ppul.24927.

16. Tadolini M, Codecasa LR, Garcia-Garcia JM, Blanc FX, Borisov S, Alffenaar JW, et al. Active tuberculosis, sequelae and COVID-19 co-infection: first cohort of 49 cases. Eur Respir J. 2020;56(1):2001398. https://doi.org/10.1183/13993003. 01398-2020

17. Tham SM, Lim WY, Lee CK, Loh J, Premkumar A, Yan B, et al. Four patients with COVID-19 and tuberculosis, Singapore, April-May 2020. Emerg Infect Dis. 2020. https://doi.org/10.3201/eid2611.202752.

18. Baig AM, Khaleeq A, Ali U, Syeda H. Evidence of the COVID-19 virus targeting the CNS: tissue distribution, host-virus interaction, and proposed neurotropic mechanisms. ACS Chem Neurosci. 2020;11:995-8.

19. Bodro M, Compta Y, Llanso L, Esteller D, Doncel-Moriano A, Mesa A, et al. Increased CSF levels of IL-1 $\beta$, LL-6, and ACE in SARS-CoV-2-associated encephalitis. Neurol Neuroimmunol Neuroinflamm. 2020;7:e821. https://doi. org/10.1212/NXL000000000000821.

20. Chiang SS, Khan FA, Milstein MB, Tolman AW, Benedetti A, Starke JR, Becerra MC. Treatment outcomes of childhood tuberculous meningitis: a systematic review and meta-analysis. Lancet Infect Dis. 2014;14:947-57.

21. Solomons RS, Goussard P, Visser DH, Marais BJ, Gie RP, Schoeman JF, et al. Chest radiograph findings in children with tuberculous meningitis. Int J Tuberc Lung Dis. 2015;19:200-4.

22. Marais S, Thwaites G, Schoeman JF, Török ME, Misra UK, Prasad K, et al. Tuberculous meningitis: a uniform case definition for use in clinical research. Lancet Infect Dis. 2010:10:803-12.

23. Sallard E, Lescure FX, Yazdanpanah Y, Mentre F, Peiffer-Smadja N. Type I interferons as a potential treatment against COVID-19. Antivir Res. 2020;178: 104791. https://doi.org/10.1016/j.antiviral.2020.104791 [Epub ahead of print].

24. Wei L, Ming S, Zou B, Wu Y, Hong Z, Li Z, et al. Viral invasion and type I interferon response characterize the immunophenotypes during COVID-19 infection (March 17, 2020). Available at SSRN: https://doi.org/10.2139/ssrn. 3555695.

25. Trouillet-Assant S, Viel S, Gaymard A, Pons S, Richard JC, Perret M, et al. Type I IFN immunoprofiling in COVID-19 patients. J Allergy Clin Immunol. 2020; 146:206-8.e2.

26. Pathak S, Wentzel-Larsen T, Åsjö B. Effects of in vitro HIV-1 infection on mycobacterial growth in peripheral blood monocyte-derived macrophages. Infect Immun. 2010;78:4022-32.

27. Whittaker E, López-Varela E, Broderick C, Seddon JA. Examining the complex relationship between tuberculosis and other infectious diseases in children. Front Pediatr. 2019;7:233. https://doi.org/10.3389/fped.2019.00233. eCollection.

28. Redford PS, Mayer-Barber KD, McNab FW, Stavropoulos E, Wack A, Sher A, O'Garra A. Influenza A virus impairs control of Mycobacterium tuberculosis coinfection through a type I interferon receptor-dependent pathway. J Infect Dis. 2014;209:270-4.

29. Scriba TJ, Coussens AK, Fletcher HA. Human immunology of tuberculosis. Microbiol Spectr. 2017;5(1). https://doi.org/10.1128/microbiolspec.TBTB20016-2016.

30. Panteleev AV, Nikitina IY, Burmistrova IA, Kosmiadi GA, Radaeva TV, Amansahedov RB, et al. Severe tuberculosis in humans correlates best with neutrophil abundance and lymphocyte deficiency and does not correlate with antigen-specific CD4 T-cell response. Front Immunol. 2017;8:963. https://doi.org/10.3389/fimmu.2017.00963.

31. Kunchok A, Zekeridou A, McKeon A. Autoimmune glial fibrillary acidic protein astrocytopathy. Curr Opin Neurol. 2019;32:452-8.

32. Yousaf Z, Al-Shokri SD, Al-Soub H, Mohamed MFH. Covid-19 associated SIADH; a clue in the times of pandemic. Am J Physiol Endocrinol Metab. 2020;318:E882-5.

\section{Publisher's Note}

Springer Nature remains neutral with regard to jurisdictional claims in published maps and institutional affiliations.

Ready to submit your research? Choose BMC and benefit from:

- fast, convenient online submission

- thorough peer review by experienced researchers in your field

- rapid publication on acceptance

- support for research data, including large and complex data types

- gold Open Access which fosters wider collaboration and increased citations

- maximum visibility for your research: over $100 \mathrm{M}$ website views per year

At $\mathrm{BMC}$, research is always in progress.

Learn more biomedcentral.com/submission 